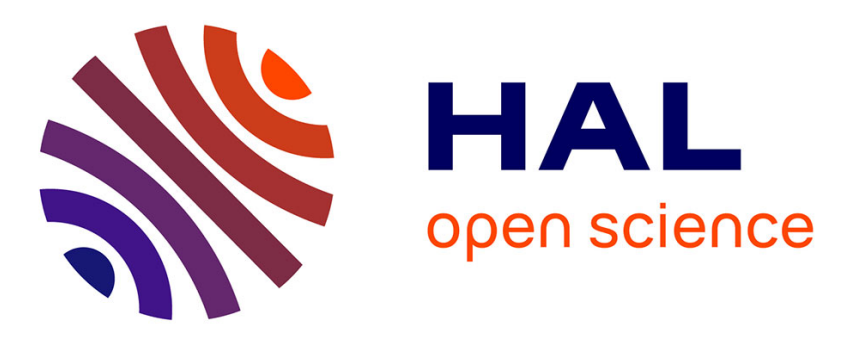

\title{
Enhanced photocatalytic activity of sputter-deposited nanoporous BiVO4 thin films by controlling film thickness
}

Siavash Bakhtiarnia, Saeed Sheibani, Alain Billard, Hui Sun, Eric Aubry, Mohammad Arab Pour Yazdi

\section{To cite this version:}

Siavash Bakhtiarnia, Saeed Sheibani, Alain Billard, Hui Sun, Eric Aubry, et al.. Enhanced photocatalytic activity of sputter-deposited nanoporous BiVO4 thin films by controlling film thickness. Journal of Alloys and Compounds, 2021, 879, pp.160463 (14). hal-03360033

\section{HAL Id: hal-03360033 https://hal.science/hal-03360033}

Submitted on 30 Sep 2021

HAL is a multi-disciplinary open access archive for the deposit and dissemination of scientific research documents, whether they are published or not. The documents may come from teaching and research institutions in France or abroad, or from public or private research centers.
L'archive ouverte pluridisciplinaire HAL, est destinée au dépôt et à la diffusion de documents scientifiques de niveau recherche, publiés ou non, émanant des établissements d'enseignement et de recherche français ou étrangers, des laboratoires publics ou privés. 


\title{
Enhanced photocatalytic activity of sputter-deposited nanoporous $\mathrm{BiVO}_{4}$ thin films by controlling film thickness
}

\author{
Siavash Bakhtiarnia ${ }^{\mathrm{a}, \mathrm{b}}$, Saeed Sheibani ${ }^{\mathrm{a}, *}$, Alain Billard ${ }^{\mathrm{b}}$, Hui Sun ${ }^{\mathrm{c}}$, Eric Aubry ${ }^{\mathrm{b}}$, \\ Mohammad Arab Pour Yazdi ${ }^{b}$ \\ a. School of Metallurgy and Materials Engineering, College of Engineering, University of \\ Tehran, Tehran, Iran. \\ b. Institut FEMTO-ST, UMR 6174, CNRS, Univ. Bourgogne Franche-Comté, 15B, Avenue \\ des Montboucons, 25030 Besançon, France ${ }^{\mathrm{c}}$. \\ ${ }^{c}$ School of Space Science and Physics, Shandong University, Weihai 264209, China
}

\begin{abstract}
In this study, nanoporous $\mathrm{BiVO}_{4}$ thin films were deposited using reactive direct-current (DC) magnetron sputtering. The effects of thickness on the film morphology, crystal structure, microstructure, composition, optical and photocatalytic properties under visible light were investigated. The film porosity and refractive index were also determined via the UV-Vis spectrophotometric technique using transmittance and reflectance spectra and Cauchy dispersion law as the fitting model. The nanoporous morphology was observed using fieldemission scanning electron microscopy (FESEM) with average pore sizes in the $20-40 \mathrm{~nm}$ range. The X-ray diffraction (XRD) results showed different texture grades corresponding to the (040) crystallographic plane, establishing the film thickness influence on the preferential orientation. The X-ray photoelectron spectroscopy (XPS) was also implemented to investigate the chemical state of the film surface, as well as to determine the valence band position. The film $715 \mathrm{~nm}$ in thickness showed the highest porosity (52\%), narrowest bandgap $(2.44 \mathrm{eV})$, highest exposed (040) crystallographic plane and highest visible-light-driven photodegradation towards Rhodamine- $\mathrm{B}(\mathrm{RhB})$ solution. The $\mathrm{pH}$ of the solution also impacted the $\mathrm{RhB}$ photodegradation which was optimum at $\mathrm{pH}=3$ with chromophore cleavage pathway dominance, whereas at neutral $\mathrm{pH}$ it had distinctively slow kinetics probably due to poor electrostatic interactions and the N-deethylation kinetics bottleneck. The photocatalytic cycle experiments exhibited high stability and recyclability of $\mathrm{BiVO}_{4}$ thin-film photocatalysts after four cycles $(4 \times 7 \mathrm{~h})$ of exploitation. The photocatalytic mechanism was determined using scavengers and the significance of hydroxyl radicals and photogenerated holes were established. The photocatalytic activity reached $97 \%$ after $7 \mathrm{~h}$ of illumination with a $400 \mathrm{~W}$ light source.
\end{abstract}

Keywords: $\mathrm{BiVO}_{4}$; Thin film; Thickness; Sputtering; Photocatalyst

Journal of Alloys and Compounds 879 (2021) 160463

https://doi.org/10.1016/j.jallcom.2021.160463 